\title{
Optimization of Agrobacterium-mediated transformation parameters for sweet potato embryogenic callus using $\beta$-glucuronidase (GUS) as a reporter
}

\author{
Yujun Xing ${ }^{1,2}$, Qing Yang ${ }^{1}$, Qin $\mathrm{Ji}^{2 \star}$, Yuming $\mathrm{LuO}^{2}$, Yunfeng Zhang ${ }^{2}, \mathrm{Ke} \mathrm{Gu}^{2}$ and Dengzhan \\ Wang $^{2}$ \\ ${ }^{1}$ College of Life Sciences, Nanjing Agricultural University, Nanjing 210095, China. \\ ${ }^{2}$ Department of Biology, Huaiyin Teachers College, Huaiyin, 223300, China.
}

Accepted 23 October, 2007

\begin{abstract}
Agrobacterium-mediated transformation factors for sweet potato embryogenic calli were optimized using $\beta$-glucuronidase (GUS) as a reporter. The binary vector pTCK303 harboring the modified GUS gene driven by the CaMV $35 \mathrm{~S}$ promoter was used. Transformation parameters were optimized including bacterial concentration, pre-culture period, co-cultivation period, immersion time, acetosyringone (AS) concentration and mannitol treated time. Results were obtained based on the percentage of GUS expression. Agrobacterium tumefaciens strain EHA105 at concentration $\mathrm{OD}_{600 \mathrm{~nm}}=0.8$ showed the highest virulence on sweet potato embryogenic callus. Four days of pre-culture, four days of co-cultivation, $10 \mathrm{~min}$ of immersion, $200 \mu \mathrm{M}$ acetosyringone and $60 \mathrm{~min}$ of mannitol-treated embryogenic callus gave the highest percentage of GUS positive transformants.
\end{abstract}

Key words: Agrobacterium-mediated, transformation parameters, sweet potato embryogenic callus, $\beta$-glucuronidase.

\section{INTRODUCTION}

The sweet potato (Ipomoea batatas (L) Lam.) is the sixth most important crop in the world, right after wheat, rice, corn, white potato and barley (Vietmeyer, 1986). Approximately $98 \%$ of the sweet potatoes are grown in the tropical and temperate zones of the developing world for the edible storage roots and foliage and is a valuable source of food, animal feed and industrial raw material. Sweet potato improvement through conventional breeding is very useful but is complicated. Although sweet potato has some advantage, such as its clonal propagation, ease of cultivation and high productivity of storage roots and foliage, male sterility, incompatibility and a hexaploid genome make it difficult to improve by conventional

${ }^{\star}$ Corresponding author. E-mail: jiqin1003@yahoo.com.cn. Tel: +86-517-3525382. Fax: +86-517-3525992.

Abbreviations: 2,4-D, 2,4-dichlorophenoxyacetic acid; AS, acetosyringone; CIM, callus induced medium; GUS, $\beta$-Glucuronidase; MS, Murashige and Skoog; rpm, rotate per minute; CCM, co-cultured medium. breeding (Sihachakr and Ducreux, 1987).

At present, it is important to develop a genetic transformation system for introduction of exogenous genes into plants in order to improve the plants quality and develop new varieties. There are several methods vailable for transferring desired genes into plant genome such as Agrobacterium-mediated method, micro-projectile bombardment and electroporation. Among these methods, Agrobacterium- mediated is the most commonly used system which involves the delivering of DNA from Agrobacterium plasmid into cells of a wide variety of dicotyledonous and some monocotyledonous plants, and the Agrobacterium-based transformation method possess several advantages over other forms of transformation, including: (1) the ability to transfer large segments of DNA with minimal rearrangement, (2) the precise insertion of transgenes resulting in fewer copies of inserted genes, and (3) simple technology with lower cost (Binns, 1990).

Reporter genes have been used as convenient markers to visualize gene expression and protein localization in vivo in a wide spectrum of prokaryotes and eukaryotes (Jefferson, 1987). Commonly used reporters include 


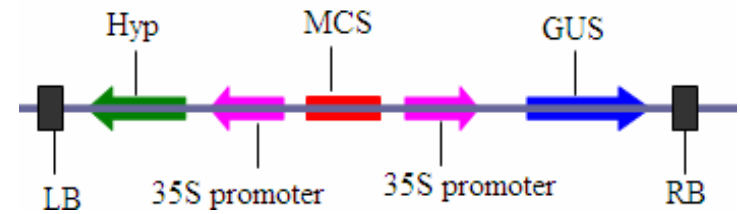

Figure 1. Schematic representation of T-DNA region of binary vector pTCK303. MCS, multiple clone sites; LB, Left border; RB, right border.

genes encoding chloramphenicol acetyl transferase (CAT), green fluorescent protein (GFP) luciferase (LUC), and $\beta$-glucuronidase (GUS). In this study, the Agrobacterium-mediated transformation system for sweet potato embryogenic callus was optimized by using GUS as a reporter. There was no system report of genetic transformation carried out on this sweet potato cultivar until now. The effects of parameters such as bacterial concentration, pre-culture period, co-cultivation period, immersion time, acetosyringone (AS) concentration and mannitol treated time were assessed. These parameters are known to influence the transformation efficiency and the optimized conditions are host species dependent.

\section{MATERIALS AND METHODS}

Plant material and establishment of embryogenic suspension callus

Sweet potato cultivar Xu55-2 was used as a plant material which was a cultivar well adapted to the China region. The emerged buds (about $1-1.5 \mathrm{~cm}$ ) were cut and surface sterilized in $0.1 \% \mathrm{HgCl}_{2}$ solution with a drop of Tween-20 for 3 min after washing in the tap water and $70 \%$ ethanol treatment for $30 \mathrm{~s}$. The buds were then rinsed five times with sterile distilled water. The meristematic tissues of tips (about $1 \mathrm{~mm}$ in length) were cut from sterilized buds under the microscope and cultured on MS basic medium (Murashige and Skoog, 1962) complemented with 2 mg.L-1 2,4-dichlorophenoxyacetic acid (CIM) solid medium at $28^{\circ} \mathrm{C}$ in the dark. Callus induced from sweet potato shoot-tip were routinely subcultured at 25 days intervals. The friable and yellow granular calli were cultured in CIM liquid medium with shaking at $100 \mathrm{rpm}$ for $16 \mathrm{~h}$ light a day at $28^{\circ} \mathrm{C}$., The cultures were subcultured into fresh CIM liquid medium every week. Rapidgrowing and well-dispersed suspension calli were used as the transformation explants.

\section{Plasmids vector and Agrobacterium strain}

The binary vector pTCK303 harboring the reporter GUS driven by the CaMV (CaMV: cauliflower mosaic virus) 35S promoter was used (Figure 1). The plasmid DNA was prepared from Escherichia coli DH5a using alkaline lysis method (Sambrook et al., 1989) and introduced into Agrobacterium tumefaciens EHA105 prior to transformation of sweet potato. The concentration of plasmid yield was determined by a spectrophotometer. The plasmid vector was transformed into Agrobacterium strains according to using liquid nitrogen freeze-thaw modified method (An, 1988). A single colony of the Agrobacterium strain was inoculated in $25 \mathrm{ml}$ of LB $(0.5 \%$ yeast extract, $1 \%$ peptone, $1 \% \mathrm{NaCl}$ ) liquid with appropriate antibiotics and incubated overnight with $200 \mathrm{rpm}$ shaking at $28^{\circ} \mathrm{C}$. Subsequently, 1 $\mathrm{ml}$ of above liquid culture was inoculated in $20 \mathrm{ml}$ of fresh LB and incubated with $200 \mathrm{rpm}$ shaking at $28^{\circ} \mathrm{C}$ until the $\mathrm{OD}_{600 \mathrm{~nm}}$ reached 0.8 . The cells were precipitated at $5000 \mathrm{~g}$ for $10 \mathrm{~min}$ at $4^{\circ} \mathrm{C}$ and the pellet was resuspended in $10 \mathrm{ml}$ of $0.1 \mathrm{M} \mathrm{CaCl}_{2}$. The bacteria cells were centrifuged again at $5000 \mathrm{~g}$ for $10 \mathrm{~min}$ at $4^{\circ} \mathrm{C}$ and resuspended in $1 \mathrm{ml}$ of ice-cold $0.1 \mathrm{M} \mathrm{CaCl}_{2}$. The cells $(0.2 \mathrm{ml})$ were transferred to a $1.5 \mathrm{ml}$ eppendorf tube and $10 \mathrm{ng}$ of recombinant plasmid DNA was added, mixed and incubated on ice for $30 \mathrm{~min}$. The mixture was frozen in liquid nitrogen for $5 \mathrm{~min}$, and then thawed at $37^{\circ} \mathrm{C}$ water bath for five min. The $0.8 \mathrm{ml}$ LB medium (no antibiotics) were added to the mixture and incubated with $200 \mathrm{rpm}$ shaking at $28^{\circ} \mathrm{C}$ for $4-6 \mathrm{~h}$. The cells were collected by centrifuging at $5000 \mathrm{~g}$ for $5 \mathrm{~min}$ and resuspended in $0.1 \mathrm{ml}$ of $\mathrm{LB}$ liquid. The bacteria cells were then spread on LB plates (LB medium containing $1.5 \%$ agar) with appropriate antibiotics and incubated at $28^{\circ} \mathrm{C}$ for 2 to 3 days for the selection of bacteria containing the recombinant plasmid DNA. The untransformed calli were spread on another plate containing antibiotic as a control. The resultant antibiotic resistant colonies were checked for the presence of vector. The engineered strains of Agrobacterium were maintained and used for plant transformations.

\section{Agrobacterium-mediated transformation of sweet potato}

The $A$. tumefaciens strain EHA105 was grown overnight on a shaker at $200 \mathrm{rpm}$ and at a temperature of $28^{\circ} \mathrm{C}$. The suspension cells were centrifuged at $5000 \mathrm{~g}$ for $10 \mathrm{~min}$ and the pellets were resuspended in an equivalent volume of liquid MS medium. Embryogenic suspension callus as described above were prepared and transfer into Agrobacterium suspension. The bacterial and calli were then mixed and gently shaken to ensure that the entire calli fully submerged (De Bondt et al., 1994). After immersion for an appropriate incubation time, the calli were blotted dry on sterile filter paper and transferred to the co-cultivation liquid medium (CCM: CIM + $100 \mu \mathrm{M}$ AS (except in AS different concentration experiment) ). For the control, the calli were directly placed on co-cultivation medium without being immersed in Agrobacterium suspension. The calli were co-cultivated at $28^{\circ} \mathrm{C}$ in dark for 4 days. At the end of the co-cultivation period, the embryogenic suspension calli were detected by histochemical localization of GUS activity.

\section{Histochemical localization of GUS activity and statistical analysis}

In this research, the effects of the following parameters known to influence the transformation efficiency were assessed: bacterial concentration $\left(0.4,0.6,0.8,1.0\right.$ and 1.2 at $\left.\mathrm{OD}_{600 \mathrm{~nm}}\right)$, pre-culture period $(1$, $2,3,4,5,6$ and 7 days), co-cultivation period (1, 2, 3, 4, 5, 6 and 7 days), immersion time $(4,6,8,10,12$ and $14 \mathrm{~min})$, AS concentration $(0,100$, $200,300,400$ and $500 \mu \mathrm{M})$ added to $\mathrm{CCM}$ and mannitol treated time (0, $20,40,60$ and $80 \mathrm{~min}$ ). All the parameters were optimized by screening for transient GUS expression using histochemical localization of GUS activity. All experiments were carried out with 20 samples and repeated three times. The statistical analyses were performed using SPSS 11.0 (SPSS Inc. USA) at 5\% level.

GUS assay was carried out according to the method described by (Jefferson, 1989). After co-cultured, embryogenic calli were incubated in a solution containing $100 \mathrm{mM} \mathrm{Na}_{3} \mathrm{PO}_{4}(\mathrm{pH} 7.0), 10 \mathrm{mM}$ EDTA, $\quad 0.5 \mathrm{mM} \mathrm{K} \mathrm{K}_{3} \mathrm{Fe}(\mathrm{CN})_{6}, \quad 0.5 \mathrm{mM} \mathrm{K} \mathrm{K}_{4} \mathrm{Fe}(\mathrm{CN})_{6}, \quad 1 \mathrm{mg} / \mathrm{mL}$ 5-bromo-4-chloro-3-indolyl- $\beta$-D-GlcUA (X-Gluc) and $0.1 \%$ Triton $\mathrm{X}-100$ at $37^{\circ} \mathrm{C}$ for $2 \mathrm{~h}$. The stained tissues were then transformed into $95 \%$ ethanol for $24 \mathrm{~h}$ to remove chlorophylls. No transformed sweet potato suspension calli were used as control.

\section{RESULTS}

The efficiency of sweet potato embryogenic suspension 


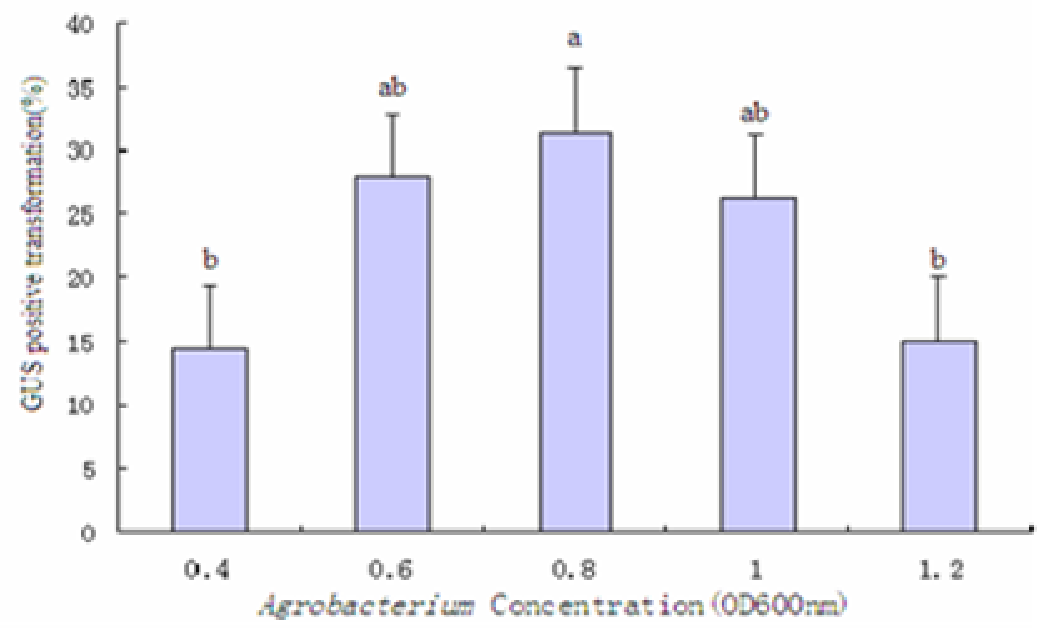

Figure 2. Effect of bacterial concentration on transformation efficiency of sweet potato embryogenic suspension callus. (Error bars correspond to standard deviation $(n=3)$ ). Different letters indicate values are significantly different $(p \leq 0.05)$.

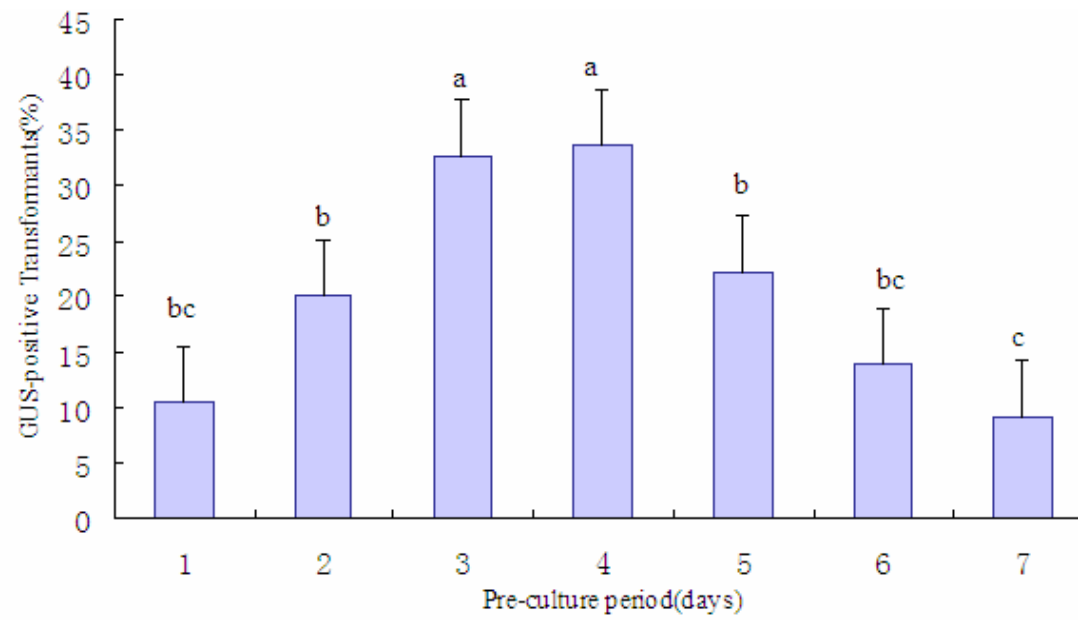

Figure 3. Effect of pre-culture period on transformation efficiency of sweet potato embryogenic suspension callus. (Error bars correspond to standard deviation $(n=3))$. Different letters indicate values are significantly different $(p \leq 0.05)$.

cell transformation was influenced by several factors such as bacterial concentration, pre-culture period, co-cultivation period, immersion time, AS concentration and mannitol treated time. The results obtained are based on the percentage of GUS positive transformants.

\section{Bacterial concentration}

Observation on the effect of bacterial concentration on transformation efficiency was carried out and the result was shown in Figure 2. In the study, $\mathrm{OD}_{600 \mathrm{~nm}}=0.8$ of EHA105 gave the highest transformation efficiency for sweet potato embryogenic suspension callus. Although
$\mathrm{OD}_{600 \mathrm{~nm}}=0.8$ gave the highest percentage of GUS positive transformants, there was no significant difference $\left(p \leq 0.05\right.$ ) among $\mathrm{OD}_{600 \mathrm{~nm}}=0.6,0.8,1.0$ and it was found that higher $\mathrm{OD}_{600 \mathrm{~nm}}$ significantly decreased the transformation efficiency for sweet potato embryogenic suspension callus.

\section{Pre-culture period}

This study chose different day as the pre-culture period after embryogenic calli were transferred to fresh CIM liquid medium. The results are showed in Figure 3. Although there was no significant difference $(p \leq 0.05)$ between 3 


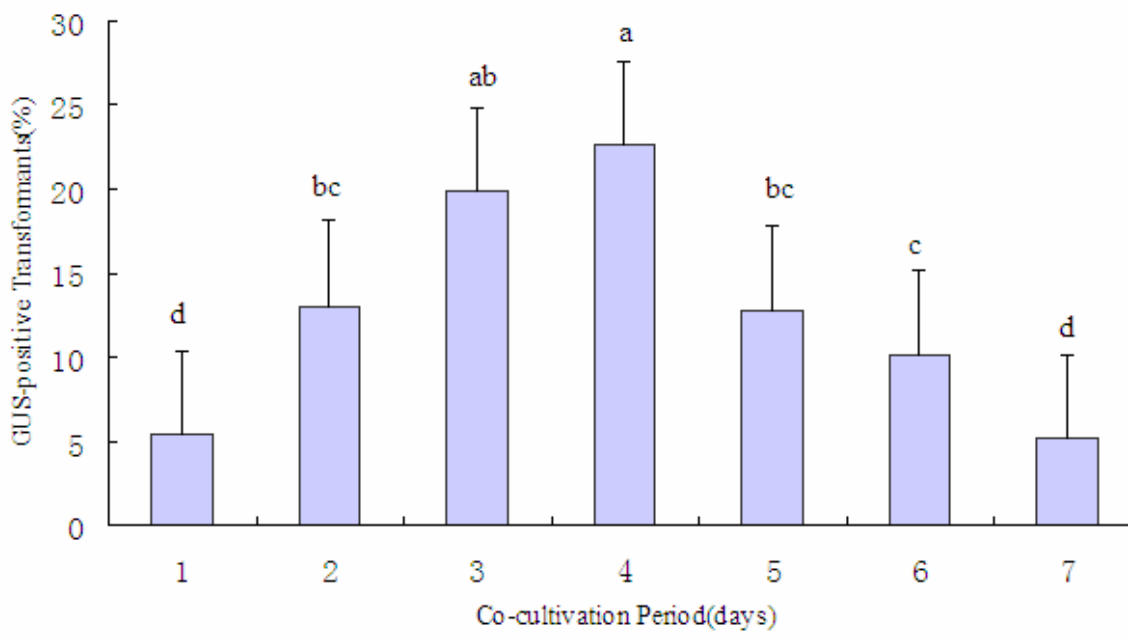

Figure 4. Effect of co-cultivation period on transformation efficiency of sweet potato embryogenic suspension callus. (Error bars correspond to standard deviation $(n=3)$ ). Different letters indicate values are significantly different $(p \leq 0.05)$.

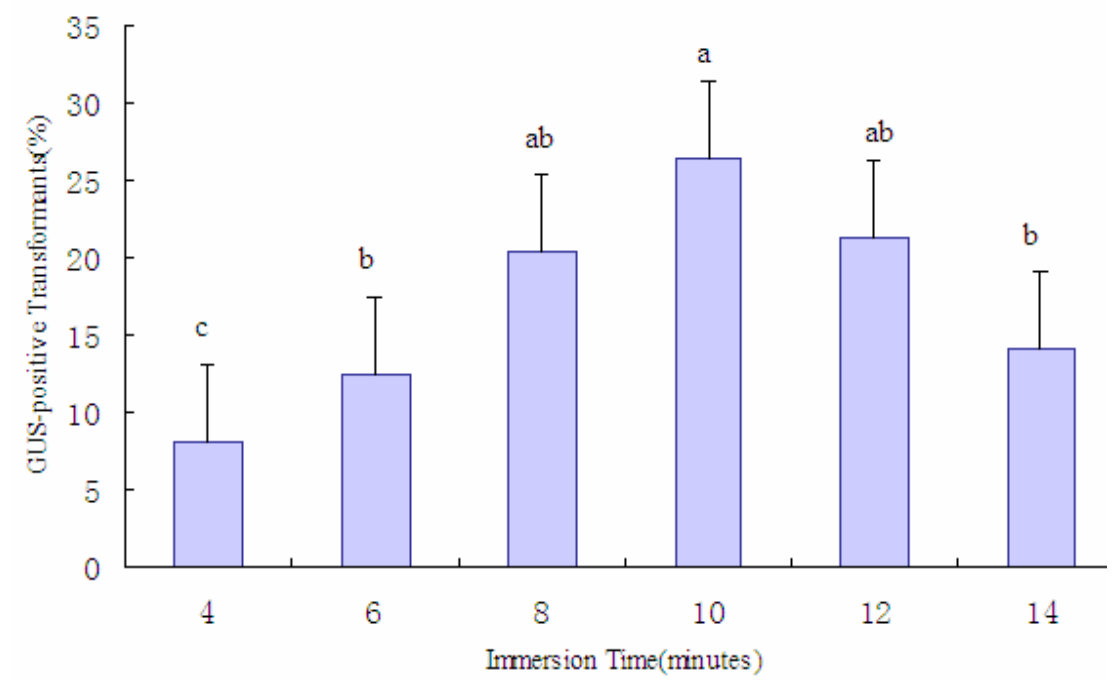

Figure 5. Effect of immersion time on transformation efficiency of sweet potato embryogenic suspension callus. (Error bars correspond to standard deviation $(n=3)$ ). Different letters indicate values are significantly different $(p \leq 0.05)$.

and 4 days of pre-culture period for sweet potato embryogenic suspension callus, 4 days of pre-culture gave the highest transformation efficiency for sweet potato embryogenic suspension callus. Therefore 4 days was chosen as the pre-culture period in the study.

\section{Co-cultivation periods}

Embryogenic calli were transferred to CCM after being immersed by Agrobacterium strain. Investigation on the effect of co-cultivation period on sweet potato embryogenic suspension callus is shown in Figure 4. Although there was no significant difference $(p \leq 0.05)$ between 3 and 4 days of co-cultivation period for sweet potato embryogenic suspension callus, the highest percentage of GUS positive transformants was presented by 4 days of co-cultivation.

\section{Immersion time}

Embryogenic calli were immersed different time by Agrobacterium strain. Figure 5 showed the effect of immersion time on sweet potato embryogenic suspension callus. Results indicated that $10 \mathrm{~min}$ was optimum for transforming embryogenic suspension callus. Although 


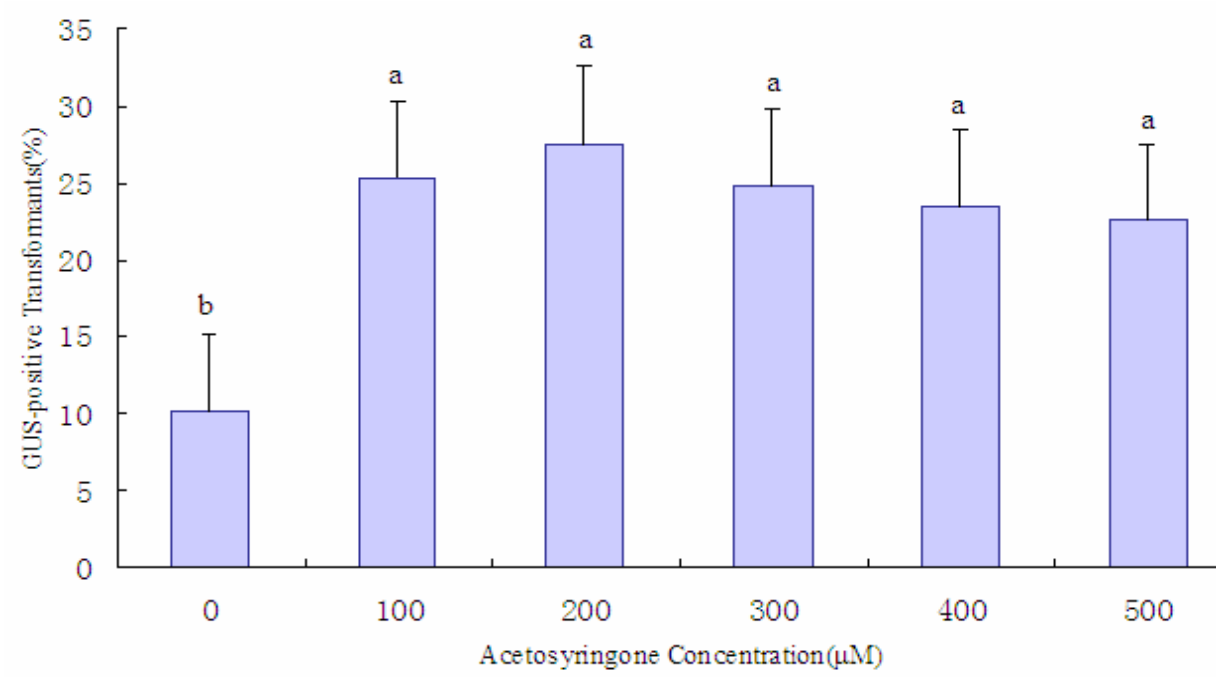

Figure 6. Effect of AS concentration on transformation efficiency of sweet potato embryogenic suspension callus. (Error bars correspond to standard deviation $(n=3)$ ). Different letters indicate values are significantly different $(p \leq 0.05)$.

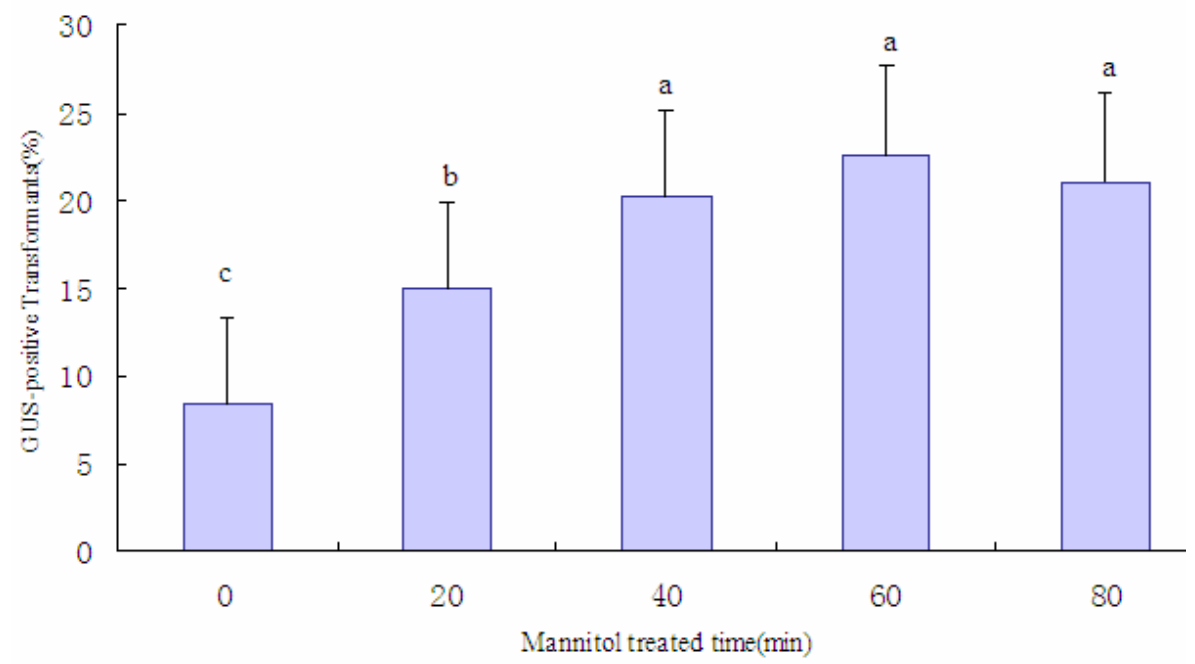

Figure 7. Effect of mannitol treated time on transformation efficiency of sweet potato embryogenic suspension callus. (Error bars correspond to standard deviation $(n=3)$ ). Different letters indicate values are significantly different $(p \leq 0.05)$.

there was no significant difference $(p \leq 0.05)$ between 8 , 10 and $12 \mathrm{~min}, 10 \mathrm{~min}$ was chosen as the immersion time in order to get high transformation efficiency.

\section{AS concentration}

AS was added to CCM. The CCM were CIM complemented with different concentration AS. The result is showed in Figure 6 and there was no significant difference ( $p \leq 0.05$ ) among $100,200,300,400,500 \mu \mathrm{M}$ AS on the GUS transformation efficiency. However, the highest effect was that of $200 \mu \mathrm{M}$ AS on enhancement of sweet potato embryogenic suspension callus responses to strains EHA105 by GUS assay.

\section{Mannitol treated time}

Embryogenic calli were treated different time by mannitol before they were mixed with bacterial. Figure 7 showed that transformation was significant improved $(p \leq 0.05)$ in the mannitol treated calli. But there was not significant difference $(p \leq 0.05)$ between 40,60 and 80 min treated 


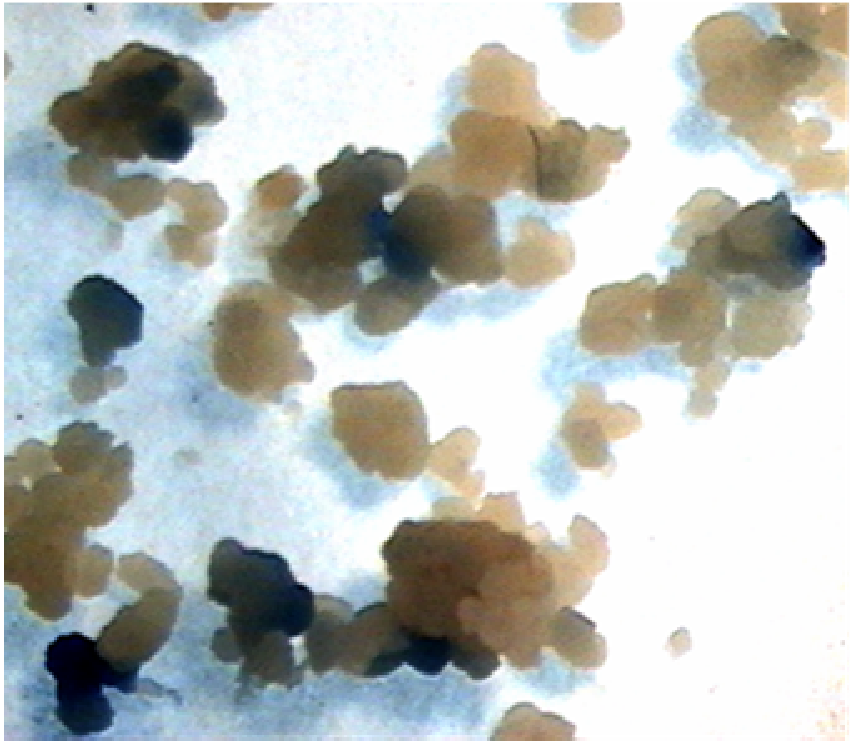

Figure 8. Sweet potato embryogenic callus showing transient GUS activity after 4 days of co-cultivation with Agrobacterium tumefaciens EHA105 (pTCK303). The blue color callus was positive and had transient GUS expression; no color callus was not transformed after co-cultivation with EHA105 and had not transient GUS expression.

calli with mannitol. However, the percentage of GUS-positive transformant was highest using mannitol treatment for $60 \mathrm{~min}$.

\section{GUS activity}

Stable GUS activity was detected in sweet potato embryogenic callus developing from embryogenic suspension callus. The tissues of transformed callus showed blue color when it was detected using X-gluc. The control callus did not show blue color (Figure 8).

\section{DISCUSSION}

Comparison between different concentrations of bacterial was also carried out on apple transformation by De Bondt et al. (1994) and showed that the Agrobacterium concentration for transformation was strain dependent. Wilson et al. (2006) showed that $\mathrm{OD}_{600 \mathrm{~nm}}=0.8$ of EHA105 had the highest transformation efficiency for Tibouchina semidecandra. Gama et al. (1996) found that $\mathrm{OD}_{600 \mathrm{~nm}}=$ 0.6 was effective for sweet potato embryogenic callus. Besides that, $\mathrm{OD}_{600 \mathrm{~nm}}=0.3-0.6$ was used for other sweet potato cultures (Otani et al., 1998). In this study, $\mathrm{OD}_{600 \mathrm{~nm}}=$ $0.6-0.8$ of EHA105 showed the highest transformation efficiency for sweet potato embryogenic callus.

Duration of pre-culture and co-cultivation showed significant effect on transformation efficiency. Pre-cultivation allowed proliferation of the plant cells to provide a large population of competent cells as potential targets for transformation. Co-cultivation led to the induction of virulence and gene transfer. Pre-culture period was found to be unnecessary for all protocols and mostly were dependent on the target plant species that had been selected (Wahlroos et al., 2003). As far as sweet potato embryogenic calli is concerned, pre-culture is necessary to improve the percentage of GUS expression. In this study, 4 days of pre-culture was ideal. Co-cultivation period has great influence on transformation too. Too short co-cultivation period is not favorable for transformation. However, too long co-cultivation period results in overgrowing agrobacterium and therefore is harmful to plant cells (Wang and Fang, 1998). Normally 2-3 days of co-cultivation are standard for most transformation protocols (Men et al., 2003; Weber et al., 2003) and longer period than that may cause necrosis and cell death. However, Prakash et al. (1991) showed the co-culture period was not less than 4 days, and Otani et al. (1998) found that 2 days can be used to co-culture period. From above, the difference in co-culture period is due to the species and explants.

Immersion time also varied between plant species and tissue types. Immersion of explants in Agrobacterium suspension enhanced the attachment of Agrobacterium to the explants. The addition of AS as a phenolic inducer may also influence the transformation efficiency. Pineda et al. (2002) showed that there was increase in GUS expression because of the presence of $200 \mu \mathrm{M}$ AS on plantain embryogenic callus suspensions transformation. Khanna and Raina (1999) also stated that $400-500 \mu \mathrm{M}$ AS will enhance the transformation of rice. In this study, $100-500$ $\mu \mathrm{M}$ AS enhanced the GUS expression and promoted the trans- formed efficiency.

Sweet potato embryogenic calli treated by mannitol is importance for efficient transformation. Vain et al. (1993) showed that GUS expression was improved 2 times after 0.2 mol. $\mathrm{L}^{-1}$ mannitol treatment in maize embryogenic callus. Nandadeva et al. (1999) also stated that the reporter gene was promoted to express by $0.5-0.6 \mathrm{~mol}^{-\mathrm{L}^{-1}}$ mannitol in rice embryogenic callus. Therefore, mannitol is good for sweet potato embryogenic callus transformation.

\section{ACKNOWLEDGMENTS}

This work was supported by the Natural Foundation of China, project no. 30571183. Jiangsu Education Department (No.JHB04-043) and Jiangsu "Liu da ren cai" Research Projects (Agriculture B).The authors wish to thank Li Qiang and Wang Xin for providing sweet potato cultivar Xu55-2 and Dou Bing-de for providing the plasmid pTCK303.

\section{REFERENCES}

An GPR, Ebert A, Mitra SBH (1988). Plant Molecular Biology Manual, Kluwer Academic Press, Dordrecht. 
Binns AN (1990). Agrobacterium-mediated gene delivery and the biology of host range limitations. Physiol. Plant. 79: 135-139.

De Bondt A, Eggermont K, Druart P, Vil MD, Goderis L, Vanderleyden J, Broekaert WF (1994). Agrobacterium-mediated transformation of apple (Malus_domestica Borkh.): an assessment of factors affecting gene transfer efficiency during early transformation steps. Plant Cell Rep.13: 587-593.

Gama MCS, Leite JR, Cordeiro AR, Cantliffe DJ (1996). Transgenic sweet potato plants obtained by Agrobacterium tumefaciens-mediated transformation. Plant Sci. Tissue Organ Cult. 46: 237-244.

Jefferson RA (1987). Assaying chimeric gene in plants: the GUS gene fusion system. Plant Mol. Biol. Rep. 5: 387-405.

Jefferson RA (1989). The GUS reporter gene system. Nature 342: 837838.

Khanna HK, Raina SK (1999). Agrobacterium-mediated transformation of indica rice cultivars using binary and superbinary vectors. Aust. J. Plant Physiol. 26: 311-324.

Men SZ, Ming XT, Liu RW, Wei CH, Li Y (2003). Agrobacterium-mediated genetic transformation of a Dendrobium orchid. Plant Cell Tissue Organ Cult. 75: 63-71.

Murashige T, Skoog F (1962). A revised medium for rapid growth and bioassay with tobacco tissue cultures. Physiol. Plant. 15: 473-497.

Nandadeva YL, Lupi CG, Meyer CS, Devi PS, Potrykus I, Bilang R (1999). Microprojectile-mediated transient and integrative transformation of rice embryogeaic suspension cells: effects of osmotic cell conditioning and of the physical configuration of plasmid DNA. Plant Cell Rep. 18: 500-504.

Otani M, Shimada T, Kimura T, Saito A (1998). Transgenic plant production from embryogenic callus of sweet potato (Ipomoea batatas (L.)) using Agrobaterium tumefaciens. Biotechnology. 15: 11-16.

Pineda CR, Toro PN, Narvaez J, Orozco Cardenas ML, Laignelet A, Cárdenas H (2002). Genetic transformation by Agrobacterium tumefaciens of embryogenic cell suspensions of plantain "dominico Harton" (Musa AAB Simmonds). Informusa.11: 9-13.

Prakash CS, Varadarajan U, Kumar AS (1991). Foreign gene transfer to sweet potato Ipomoea batatas (L.). Hortscience. 26: 492.

Sambrook J, Fritsch EF, Maniatis T (1989). Molecular Cloning: A Laboratory Manual. Cold Spring Harbor Laboratory, New York.
Sihachakr D, Ducreux G (1987). Plant regeneration from protoplast culture of sweet potato (Ipomoea batatas (L.) Lam.). Plant Cell Rep. 6: 326-328

Vain P, Michael DM, Finer JJ (1993). Treatment enhances particle bombardment -mediated transient and stable transformation of maize. Plant Cell Rep. 12: 84-88.

Vietmeyer ND (1986). Lesser-known plants of potential use in agriculture and forestry. Science. 232: 1379-1384.

Wahlroos T, Susi P, Tylkina L, Malyshenko S, Zvereva S, Korpela T (2003). Agrobacterium-mediated transformation and stable expression of the green fluorescent protein in Brassica rapa. Plant Physiol. Biochem. 41:773-778.

Wang GL, Fang HJ (1998). Mechanism and technology of plant genetic engineering, Science Publisher, Beijing.

Weber S, Friedt W, Landes N, Molinier J, Himber C, Rousselin P, Hahne G, Horn R (2003). Improved Agrobacterium-mediated transformation of sunflower (Helianthus annuus (L)): assessment of macerating enzymes and sonication. Plant Cell Rep. 21: 475-482.

Wilson TLY, Janna OA, Maziah M (2006). Optimization of Agrobacterium-mediated transformation parameters for Melastomataceae spp. using green fluorescent protein (GFP) as a reporter. Sci. Hortic. 109: 78-85. 